\title{
Sanctions on Children: Comparative Studies of Indonesia and Netherlands
}

\author{
Rafika Nur $^{1} \quad$ Marwati Riza $^{2} \quad$ Andi Pangerang Moenta ${ }^{2} \quad$ Handar Subhandi Bakhtiar $^{3}$ \\ 1. Lecturer, Faculty Of Law, Ichsan University Of Gorontalo and Doctoral Student, Faculty Of Law, Hasanuddin \\ University, Indonesia \\ 2. Professor, Faculty Of Law, Hasanuddin University, Indonesia \\ 3. Doctoral Student, Faculty Of Law, Hasanuddin University, Indonesia
}

\begin{abstract}
Sanctions are a means of law enforcement, the sanction system has enormous implications for imposing and implementing sanctions. Sanctions are a logical consequence of an action that is done. In Indonesia, a country that uses two types of criminal sanctions at once, namely in the form of a criminal (straf) and actions (maatregels) as well as the Netherlands. The imposition of sanctions on children is very concerned about the interests and needs of children so that the imposition of sanctions is emphasized on efforts to educate children so that in the future the child does not repeat acts that violate the law.
\end{abstract}

Keywords: Sanction, Children, Indonesia, Netherlands

DOI: $10.7176 / \mathrm{JLPG} / 98-29$

Publication date:June 30th 2020

\section{A. Introduction}

Children are part of the community, they have the same rights as other communities to be protected and respected. Any State anywhere in the world is obliged to give adequate attention and protection to the rights of the child, which include civil, economic, social and cultural rights, but it seems that the position and rights of the child when viewed from a juridical perspective have not received attention seriously both by the government, law enforcers and society in general and still far from what should be given to them. This condition is also complicated by the weak implementation of the law on the rights of the child committed by law enforcement officers themselves. ${ }^{1}$

Children are hope of nation's future, State, society, family, and because of their condition as a children, special treatment is required for them to grow and develop both physically and mentally. Children as a part of young generation is one of human resources potential as successor of the ideals of the nation's struggle in the future, have a strategic role and special features and characteristics, require counseling and protection in order to ensure the growth and development of physical, mental and social in balance manner. Counseling practices on child prisoners are more humane by maintaining the value and dignity of human beings. This treatment is intended to place child prisoners as subjects in counseling process with the ultimate goal to return child prisoners to society as a good and useful person (re-socialization). Re-socialization is one of goals of the idea of individualization of criminal sentencing that is born from modern sect thinking. ${ }^{2}$

The problem of children and their protection will never stop throughout the history of life, because children are the next generation of the nation and the next generation of development prepared as subjects for implementing sustainable development and controlling the future of a country. ${ }^{3}$ The implementation of child law in Indonesia uses Law No. 11 of 2012 concerning the children criminal justice system, hereinafter referred to as the SPPA Law, using 2 systems, namely a double track system where in implementing penalties for giving sanctions to children aged 14 years, only sanctions can be imposed but children aged 21 years are given criminal sanctions.

In carrying out the sentence, children under the age of 12 cannot be prosecuted if a child commits a minor offense, such as theft or vandalism (damaging or destroying works of art, other valuables). The police will talk to parents. They can also send children to the youth care office, who will provide counseling or refer other services. If a child under 12 years is totally out of control, the court will intervene with, for example appointing a supervisor to monitor the child. While in Indonesia the implementation of punishment on these children varies for ages 12 years and under cannot be sanctioned but for children 12-14 years are given sanctions actions and 14-21 years are given criminal sanctions but can also be sanctioned actions in accordance with the severity of the criminal acts committed.

The Netherlands has a program called Halt which is a place where teenagers who commit minor offenses can be referred to the HALT children crime prevention program. This gives teenagers the opportunity to correct their

${ }^{1}$ Sofyan, A.M., Haeranah., Bakhtiar, H.S., Criminal Justice System of Children in Indoensia, IOSR Journal Of Humanities And Social Science (IOSR-JHSS), Volume 24, Issue 9, Series. 2, September. 2019. P.1

${ }^{2}$ Nur, R., \& Bakhtiar, H.S. 2017. Model of Child Prisoners Counseling (A Comparative Study in Japan, Malaysia and Indonesia). Journal of Law, Policy and Globalization, 68, 34-40.

${ }^{3}$ Nashriana. 2014. Perlindungan hukum pidana anak di Indonesia. Jakarta: PT Raja grafindo persada.. P.1 
mistakes. They can also apologize to the victim and pay for any damage caused to their actions. If they successfully complete the halt program obligations they will not have a criminal record. And if they do not take the halt program or do not complete it completely, the public prosecutor will continue their case. ${ }^{1}$

Based on this explanation, this paper will discuss the comparison of the imposition of sanctions on children who commit crimes in Indonesia and the Netherlands. This paper is a comparative study of comparative legal systems, especially the children justice system between Indonesia and the Netherlands. The approach taken in this paper is normative juridical approach that is by examining secondary data. ${ }^{2}$ Secondary data needed include primary legal materials and secondary legal materials. There are various legislations in the field of child criminal justice system. Besides, it also tertiary legal materials such as dictionaries and encyclopedias legal law. The data have been collected and processed subsequently performed classification using the method of interpretation and construction of laws is commonly used in the science of law and further qualitative juridical analysis. ${ }^{3}$

\section{B. Analysis and Discussion}

\section{a. Criminal Justice System for Children}

The Criminal Justice System for Children is a system of control of juvenile delinquency which consists of institutions that deal with Child Investigations, Child Prosecutions, Juvenile Courts, Corrections of Children. The placement of the word "child" in juvenile justice shows the upper limit of cases handled by the judiciary, namely children's cases. In the Child Criminal Justice System is held with due regard to the welfare of children, this is important because:

a) Children are the potential and successors to the ideals of the nation whose foundations have been laid by previous generations;

b) For each child to be able to assume these responsibilities, he needs to have the opportunity to grow, develop naturally;

c) That in the community there are children who experience barriers to spiritual, physical, social, and economic well-being;

d) The child has not been able to take care of himself;

e) That removing these obstacles will only be implemented and obtained if the child welfare effort is guaranteed.

The reformist group views that settlement through the means of reasoning cannot overcome crime. The abolitionist group considers that the criminal justice practice only enforces its decision, on the basis of the interpretation of norms and values produced by consensus, which is considered the most correct (consensus model). Criminal justice based on this model has never created an understanding, neither of the perpetrators of the crime, nor of the victim. Criminal law is only hard on people, but not hard on crime.

\section{b. Restorative Justice}

For child offenders under the Convention on the Rights of the Child Article 40 contains the principles of protection of the rights of violators which generally highlight the principle of child welfare and proportionality. The principles in Article 40 include:

a) Adequate treatment of children's rights according to the child's level of understanding, getting the child to master respect for others, while trying to integrate the child back into the community;

b) Principle of legality;

c) The principle of presumption of innocence;

d) Explanation of allegations and providing legal assistance;

e) Fair examination by involving parents and child legal counsel;

f) Provision of actions to children by authorized institutions according to applicable law;

g) Provision of interpreters;

h) Protection of "privacy" children.

Restorative justice resolves cases of delinquency by repairing damage or loss caused by such delinquency behavior. Is a process of family-friendly settlement of cases (cases) of delinquency by children involving the victim and the perpetrators in a deliberation to get the best agreement for both parties. The objectives of restorative justice are:

a) Simplify the process that must be followed by children who are dealing with the law;

b) Protect the rights of victims and perpetrators;

c) Minimizing the negative impact on the criminal justice process that has to be endured for children who are in conflict with the law.

d) Involve community participation in law enforcement.

\footnotetext{
${ }^{1}$ Wittebrood, K. 2003. Juvenile Crime and Sanctions in the Netherlands. Journal of Contemporary Criminal Justice, 19(4), 435453. doi:10.1177/1043986203259135

${ }^{2}$ Soekanto, S. dan Sri Mamudji, 2006, Penelitian Hukum Normatif, Suatu Tinjauan Singkat, Jakarta : Rajagrafindo Persada. P. 50-51

${ }^{3}$ Ibid. p. $205-236$
} 
The main points of thought in the Restorative Child Justice paradigm (restorative paradigm) are as follows:

1. Purpose of Imposition of Sanctions

There is an assumption that in achieving the objective of imposing sanctions, the victim is included to have the right to be actively involved in the judicial process. Indicators of achieving the goal of imposing sanctions are achieved by looking at whether the victim has been restored, the satisfaction of the victim, the amount of compensation, the perpetrators' awareness of their actions, the amount of agreement agreed to be made, the quality of work services and the overall process. The forms of sanctions are restitution, mediation of perpetrators, victims, victim services, community restoration, direct services to victims or restorative fines. In the imposition of sanctions, it involves active perpetrators, victims and the community and law enforcers. Actors work actively to restore victims 'losses, and deal with victims / victims' representatives. The victim is active in all stages of the process and will assist in determining sanctions for the offender. The community is involved as a mediator, helping victims and supporting the fulfillment of the perpetrators' obligations. Law enforcers facilitate mediation.

\section{Rehabilitation of Actors}

The main focus of restorative justice is to benefit and build positively, so children and families are the main sources. Children are considered competent and have positive abilities, are preventive and proactive. For the rehabilitation of perpetrators, it is necessary to change the attitude of social institutions and adult behavior. The perpetrators' rehabilitation is carried out with actors who are learning by doing, counseling and therapy to motivate the active involvement of the parties

3. Community Protection Aspects

Assumptions in restorative justice about achieving community protection by collaborative efforts in the justice system and the community to develop prevention. Confinement is limited as a last resort. The community is actively responsible for supporting the implementation of the restoration. Indicators of achieving community protection restoration if recidivist numbers fall, and perpetrators are under the supervision of the community, the community feels safe and confident about the role of the juvenile justice system, involving schools, families and social institutions to prevent crime; social ties and reintegration increase.

The main purpose of restorative justice is the repair of wounds caused by his actions, and conciliation and reconciliation among victims, perpetrators, and the community. Restorative Justice also intends to restore the welfare of the community through ways to expose children's behavior to accountability for their behavior. Victims are given the opportunity to participate in the process. According to Braithwaite, revealing such methods gives birth to feelings of shame and personal and family responsibility for their wrong actions to be adequately corrected.

The real purpose of restorative justice is to restore harmony between victims and perpetrators. For victims, this means physical and psychological damage. For the offender, it means taking responsibility, facing shame, and regaining his dignity. This idea has developed rapidly, with a new major conceptual development that is the merging of the role of society

\section{c. System of Sanctions on Children In Indonesia}

Theoretically, the criminal contains more suffering, although the elements of education and guidance and supervision are the main objectives. While the action is more directed to the activities of protection, education and guidance for children.

Criminal is defined as a suffering that is intentionally inflicted or inflicted on the country by a person or several people as a result of the law (sanctions) for him for his actions that have violated the prohibition of criminal law. Criminal is an uncomfortable feeling (for example in the form of restrictions, fulfillment of certain obligations) imposed by the state through criminal justice because a person or legal entity that was convicted of violating the law legally and convicted of guilt.

The mildness of the action, the personal condition of the child, or the state at the time the act was committed or what happened then can be used as a basis for judges not to impose a criminal offense or to impose an act by considering aspects of justice and humanity. In the development of criminal law, there has been a paradigm shift in the philosophy of children justice, which initially was retributive justice, then changed to rehabilitation, then finally to restorative justice. ${ }^{1}$ The transfer of the settlement of child cases out of formal justice through diversion stipulated in international instruments of children has juridical implications for Indonesia to accommodate the diversion provisions in the laws and regulations of children in Indonesia. ${ }^{2}$ In realizing the concept of Diversity as an instrument in Restorative Justice in the Child Criminal Justice System

\footnotetext{
${ }^{1}$ Pancar Chandra Purnama \& Johny Krisnan, "Pelaksanaan Diversi Ditingkat Pengadilan Berdasarkan Undang-Undang Nomor 11 Tahun 2012 Tentang Sistem Peradilan Pidana Anak", Jurnal Varia Justicia, Vol.12, No.1, Oktober 2016, p.229

2 Nurini Aprilianda, "Implikasi Yuridis Dari Kententuan Diversi Dalam Instrumen Internasional Anak Dalam Hukum Anak Di Indonesia, Jurnal Arena Hukum, Vol.6, No.1, April 2012, p.40
} 
based on Law Number 11 of 2012, namely the settlement of criminal cases involving the perpetrators, victims, the perpetrators / families of the victims and other related parties to jointly seek a fair settlement with emphasizing restoration and not retaliation. ${ }^{1}$

Handling cases of children in conflict with the law that prioritizes the best interests of children is still far from what is expected. The government has issued special regulations governing the protection of the rights of children in conflict with the law, such as Law No. 3 of 1997 concerning Children Court and later amended to Law Number 11 of 2012 concerning the Children Justice System or Law No. 23 of 2002 concerning Child Protection and even the government has ratified the Convention on the Rights of the Child (CRC) by issuing Presidential Decree No. 36 dated August 25, 1990, and signed the Beijing Rules agreement, but it turns out that the provisions in these regulations are not the best solution for resolving cases of children in conflict with the law. ${ }^{2}$

Law Number 11 of 2012 concerning the Children Justice System which has been effective since July 31, 2014 aims to maintain the dignity of children with a restorative justice approach, a child is entitled to special protection, especially legal protection in the criminal justice system. Therefore, the Criminal Justice System for Children is not only emphasized on the imposition of criminal sanctions for children who commit crimes, but also focuses on the thought that the imposition of sanctions is intended as a means of realizing the welfare of children of the perpetrators of these crimes. This is in line with the objectives of the International Criminal Justice System as desired by the international community. ${ }^{3}$

The special criminal justice system for children certainly has a specific purpose for the future interests of children and society in which the principles of restorative justice are contained. Article 1 point (6) of Law Number 11 Year 2012 concerning the Child Criminal Justice System states, restorative justice is the settlement of criminal cases involving the perpetrators, victims, the perpetrators / victims' families, and other related parties to jointly seek a solution fair by emphasizing restoration back to its original state, and not retaliation.

The mildness of the action, the personal condition of the child, or the state at the time the act was committed or what happened then can be used as a basis for judges not to impose a criminal offense or impose an act by considering aspects of justice and humanity.

\section{1) Criminal Sanctions}

According to Law No. 11 of 2012 concerning the Criminal Justice System for Children, children who are in conflict with the law can be sentenced to a criminal offense, namely the principal and additional crimes. By listening to article 71 paragraph 1 and paragraph 2 the main and additional crimes are regulated against children who are in conflict with the law.

\section{a. Criminal Principal}

There are several basic crimes against children, namely:

1. Criminal warnings

Criminal punishment is a minor criminal offense that does not result in restrictions on children's freedom.

2. Criminal conditions

Regarding criminal with the condition in Law No. 11 Year 2012 Regarding the Criminal Justice System for Children, divided into 3 namely:

1) Coaching outside the institution

In coaching outside the institution, which in essence is as follows:

a) In the event that the Judge determines that the Child is being fostered outside the institution, the institution where the education and guidance is determined is determined in the decision.

b) Criminal guidance outside the institution can be in the form of:

- Following the guidance and counseling program conducted by the supervisory officer

- Following therapy in a mental hospital

- Following therapy due to alcohol abuse, narcotics, psychotropic substances, and other addictive substances.

c) If during the guidance of the child violates the special requirements, the guiding officer may propose to the supervisory judge to extend the coaching period which does not exceed the maximum 2 (two) coaching periods that have not been carried out.

2) Community service

In service to the community, the main points are as follows:

a) Criminal community service is a crime intended to educate children by increasing their awareness of positive community activities.

\footnotetext{
${ }^{1}$ Hambali, A. R. 2019. Penerapan Diversi terhadap Anak yang Berhadapan dengan Hukum dalam Sistem Peradilan Pidana. Jurnal Ilmiah Kebijakan Hukum, 13(1), p 18

${ }^{2}$ Ibid.

${ }^{3}$ Ibid. p 20
} 
b) If the child does not fulfill all or part of his obligations in carrying out community service crimes without a valid reason, the guiding officer may propose to the supervisor judge to order the child to repeat all or part of the community service crime that is imposed on him.

c) Criminal community service for children is to be imposed with a minimum of 7 (seven) hours and a maximum of 120 (one hundred and twenty) hours.

3) Supervision.

In the case of criminal supervision, the main points are as follows:

a) Criminal supervision which can be imposed on a Child for a minimum of 3 (three) months and a maximum of 2 (two) years.

b) In the event that the Child is sentenced to criminal supervision, the Child is placed under the supervision of the Public Prosecutor and is guided by the Community Guidance.

And in general criminal with the condition, which in principle is as follows:

a) Criminal conditions can be imposed by the Judge in the case of imprisonment which is up to 2 (two) years.

b) In a court decision regarding a criminal with conditions, general conditions and special conditions are also determined.

c) The general condition is that the child will not commit another crime while serving a criminal term on condition.

d) Special requirements are to do or not do certain things that are determined in the judge's decision while still paying attention to the freedom of the child.

e) The criminal period with special conditions is longer than the criminal period with general conditions.

f) The term of a criminal period with a maximum term of 3 (three) years.

g) During serving the criminal period on condition, the Public Prosecutor conducts supervision and the Community Guidance conducts guidance so that the Child occupies the stipulated requirements.

h) As long as the child is serving a criminal condition, the child must attend 9 (nine) years compulsory education.

4) Job training

Job training is given to children, with the following conditions:

a) Criminal work training is carried out in institutions that carry out job training that is appropriate for the age of the child.

b) Criminal work training is subject to a minimum of 3 (three) months and a maximum of 1 (one) year.

5) Coaching in institutions

Guidance for coaching in institutions is imposed on children under the following conditions:

a) Criminal guidance in an institution is carried out in a job training place or a training institution that is held, both by the government and the private sector.

b) Criminal coaching within the institution is dropped if the circumstances and actions of the child do not endanger the community.

c) Coaching in institutions is carried out for a minimum of 3 (three) months and a maximum of 24 (twenty four) months.

d) Children who have undergone $1 / 2$ (one half) of the length of coaching in the institution and not less than 3 (three) months of good behavior are entitled to parole.

6) Prison

In imposing imprisonment there are several provisions that need to be considered as follows:

a) Criminal restrictions on freedom are imposed in the event that the child commits a felony or a criminal offense accompanied by violence.

b) Criminal restriction of freedom imposed on Children no later than $1 / 2$ (one half) of the maximum imprisonment that is threatened against adults.

c) Special minimum imprisonment does not apply to children.

d) Provisions regarding imprisonment in the Criminal Code also apply to Children as long as they do not conflict with this Law.

e) Children are sentenced to prison in LPKA if the circumstances and actions of the Child will endanger the community.

f) Criminal imprisonment that can be imposed on Children no later than $1 / 2$ (one half) of the maximum threat of imprisonment for adults.

g) Coaching in LPKA is carried out until the child is 18 (eighteen) years old.

h) Children who have undergone 1/2 (one half) of the length of training in LPKA and are of good character are entitled to parole.

i) Criminal imprisonment against children is only used as a last resort. 
j) If the crime committed by the Child is an offense that is threatened with capital punishment or life imprisonment, the sentence imposed is a maximum prison sentence of 10 (ten) years.

\section{b. Additional Crimes}

As it has been said that in addition to the principal crimes that can be imposed on children, a criminal can also be imposed in the form of:

1. Deprivation of profits derived from criminal acts

2. Fulfill customary obligations.

\section{2) Sanction of Action}

Aside from criminal sanctions, action sanctions are also known. Actions constitute sanctions for someone who is legally proven and convicted of wrongdoing with the aim of providing education and guidance and certain other actions. According to Law No. 11 of 2012 concerning the Child Criminal Justice System article 69 paragraph 2 that a child who is not yet 14 (fourteen) years old may only be subject to action.

Article 82 of Law No. 11 of 2012 is determined regarding sanctions actions that can be imposed by a judge on a child in conflict with a law that is proven to be in a guilty manner, namely:

1. Actions that are applied to children include:

a. Returns to parents / guardians

b. Submission to someone;

c. Care in a mental hospital

d. Nursing at an institution providing social welfare;

e. Obligation to attend formal education and / or training provided by government or private bodies

f. Revocation of driving license

g. Repairs due to criminal acts

2. The actions referred to in paragraph (1) letter $d$, letter e, and letter $f$ are subject to a maximum of 1 (one) year.

In the case of surrender to someone referred to is surrender to adults who are deemed competent, of good behavior, and responsible, by the Judge and trusted by the Child and this is done for the benefit of the child concerned.

\section{d. System of Sanctions on Children in Netherlands}

New child criminal law was also introduced in the Netherlands in 1995. Since the beginning of the 20th century, child criminal law has in principle been applied to young people aged between 12 and 17 years who have committed criminal violations. However, given the increasing assertiveness of young people, the legal position of children has been more in line with that of adults in the new child criminal law. Among other things, the new law regulates certain alternative sentences and increases the maximum sentence. This also greatly restrained the power of juvenile justice. Dutch policy on child crime gives priority to prevention. The steps taken under this policy are intended to prevent young people from ending up in an unfavorable situation, identify potential problems at an early stage, and resolve them as quickly as possible. All sorts of family and school programs have been developed in this context, partly intended to prevent future criminal behavior. If young people continue to commit criminal acts and thus come into contact with the police, repressive measures are available ranging from HALT referral to sentences of detention. Most young people who come into contact with the police are guilty of violations such as hooliganism, vandalism, and theft, and light sentences may be enough to ensure that they do not commit further violations. However, there are also groups of young people who commit more serious violations and / or who are ordinary violators. Heavier measures are applied to this group. ${ }^{1}$

In the Penal Code in the Netherlands, as several times amended and most recently amended into law on July 7, 1994 (stb.Tahun 1994 No. 528).

1. Article $77 \mathrm{a}$, that "Article 9 paragraph (1), 10-22a, 24c, 37-38i, 44 and articles 57-62 cannot be applied to someone who is 12 (twelve years old) but not 18 (eighteen) ) the year when the crime was committed Special provisions in articles $77 \mathrm{~d}-77 \mathrm{gg}$ apply as a substitute. The article that does not apply to children between the ages of 12-18 years includes: ${ }^{2}$

a. Article 9 paragraph (1) concerning types of principal crimes

b. Article 10-22a criminal code

c. Article $24 \mathrm{c}$ payment of installment fines

d. Article 37-38i placement in a mental hospital

e. Article 44 Penalty burdens due to position

\footnotetext{
${ }^{1}$ Wittebrood, K. 2003. Juvenile Crime and Sanctions in the Netherlands. Journal of Contemporary Criminal Justice, 19(4), 435453. doi:10.1177/1043986203259135

${ }^{2}$ Sri sutatiek. 2013. Rekonstruksi sistem sanksi dalam hukum pidana anak di Indonesia. Yogyakarta: Penerbit aswaja pressindo. P. 75-76
} 
f. Articles 57-62 concursus realist

2. Article 77b: "In the event that a person reaches the age of 16 years not 18 years at the time the offense is committed, the judge may not apply article $77 \mathrm{~g}-77 \mathrm{gg}$, and enforce the provisions in the previous chapter, if there are reasons based on the quality of the offense, the nature / character of the maker or makers of offenses or circumstances of the offenses being carried out "

3. Article 77c: In the event that a person reaches 18 years of age but has not reached 21 years at the time of the offense, the judge can apply Articles $77 \mathrm{~g}-77 \mathrm{gg}$. If there are reasons based on the nature of the maker, or the circumstances at the time of the offense. Juvenile detention criminal penalties will be carried out in prison institutions designed for that purpose may be the Minister of Justice.

4. Article $77 \mathrm{~d}$ :

a. The time limit for prosecution in article 70 , for crimes is reduced by half of the applicable grace period.

b. The provisions of paragraph (1) do not apply to crimes in articles $240 \mathrm{~b}$ and 245-250 tar committed against children by people who have reached the age of 16 at the time the offense is committed.

5. Article $77 \mathrm{~h}$ regulates criminal forms and actions against bad children. These crimes and actions are as follows:

1. Principal crime, consisting of:

a. In the case of crime: children are sentenced to prison terms or fines. The length of imprisonment threatened with children aged 12 to 16 years is 1 day to 12 months; those aged over 16 years are threatened with imprisonment between 1 day and 24 months. Threatened fines ranging from 5 guilders to 500 guilders. As a substitute sanction, the judge can impose an alternative sanction. The alternative sanctions are as follows.

1) Doing work without pay (social work) in the public interest up to a maximum of 200 hours, which is done in a period of 1 year. If a court ruling orders social work within a period not exceeding 100 hours, then the implementation will be within 6 months.

2) Carry out repairs, that is to repair the damage caused by a criminal offense, within a maximum period of 200 hours, and is done in 1 year. If the court imposes a sanction that does not exceed 100 hours, then the repair is carried out no later than 6 months.

3) Participate in an educational project, with a maximum period of 200 hours, carried out in a period of 6 months.

b. In crimes classified as violations, fines can be imposed between 5 guilders to 500 guilders.

2. Additional crimes consist of:
a. Deprivation
b. Revocation of the right to drive a vehicle (driver's license)

3. Actions consist of:

a. Placed in institutions for children for 2 years. This time period can be extended once for 2 years, in special cases it can be extended twice.

b. Must not drive a motorized vehicle.

c. Expropriation of profits obtained due to acts against the law.

d. Compensation

\section{Conclusion}

In the regulation of sanctions against children both in Indonesia and the Netherlands, they have a similarity that adheres to the double track system, where the position of the child is very much a concern in every process of law enforcement and the imposition of sanctions on children is very concerned about the interests of children as criminals. Imposition of sanctions is not part of retaliation efforts but is a step or effort so that children do not repeat unlawful acts in the future.

\section{References}

Abintoro Prakoso. 2016. Pembaharuan Sistem Peradilan Pidana Anak. Penerbit Aswaja Pressindo. Yogyakarta.

Hambali, A. R. 2019. Penerapan Diversi terhadap Anak yang Berhadapan dengan Hukum dalam Sistem Peradilan Pidana. Jurnal Ilmiah Kebijakan Hukum, 13(1),

Nur Rochaeti. Implementasi Keadilan Restorative Dan Pluralisme Hokum Dalam System Peradilan Pidana Anak Di Indonesia. Fakultas Hukum Diponegoro

Nashriana. 2014. Perlindungan hukum pidana anak di Indonesia. Jakarta: PT Raja grafindo persada.

Pancar Chandra Purnama \& Johny Krisnan, "Pelaksanaan Diversi Ditingkat Pengadilan Berdasarkan UndangUndang Nomor 11 Tahun 2012 Tentang Sistem Peradilan Pidana Anak”, Jurnal Varia Justicia, Vol.12, No.1, Oktober 2016,

Nurini Aprilianda, "Implikasi Yuridis Dari Kententuan Diversi Dalam Instrumen Internasional Anak Dalam 
Hukum Anak Di Indonesia, Jurnal Arena Hukum, Vol.6, No.1, April 2012.

Nur, R., \& Bakhtiar, H.S. 2017. Model of Child Prisoners Counseling (A Comparative Study in Japan, Malaysia and Indonesia). Journal of Law, Policy and Globalization, 68, 34-40.

Soekanto, S. dan Sri Mamudji, 2006, Penelitian Hukum Normatif, Suatu Tinjauan Singkat, Jakarta : Rajagrafindo Persada.

Sofyan, A.M., Haeranah., Bakhtiar, H.S., Criminal Justice System of Children in Indoensia, IOSR Journal Of Humanities And Social Science (IOSR-JHSS), Volume 24, Issue 9, Series. 2, September. 2019

Sri sutatiek. 2013. Rekonstruksi sistem sanksi dalam hukum pidana anak di Indonesia. Yogyakarta: Penerbit aswaja pressindo.

Wittebrood, K. 2003. Juvenile Crime and Sanctions in the Netherlands. Journal of Contemporary Criminal Justice, 19(4), 435-453. doi:10.1177/1043986203259135 